\title{
Noninvasive Evaluation of Liver Fibrosis in a Sample of Putative Inactive HBV Carriers in Rome, Italy
}

\author{
Marco Delle Monache ${ }^{(D)},{ }^{1}$ Alessio Petrelli ${ }^{D},{ }^{2}$ Alessandra Rossi, ${ }^{2}$ Roberto Cecere, ${ }^{1}$ \\ Concetta Mirisola, ${ }^{2}$ Gianfranco Costanzo, ${ }^{2}$ Chiara Francia, ${ }^{1}$ Federica Cerini, ${ }^{1}$ \\ Andrea Cavani, ${ }^{2}$ and Lorenzo Nosotti ${ }^{2}$ \\ ${ }^{1}$ Liver and Infectious Diseases Unit, L. Parodi Delfino Hospital, ASL RM5 P.le A. Moro 1, Colleferro, Rome 00034, Italy \\ ${ }^{2}$ National Institute for Health, Migration and Poverty (NIHMP), Via di San Gallicano 25/a, Rome 00153, Italy \\ Correspondence should be addressed to Marco Delle Monache; marco.dellemonache@aslroma2.it
}

Received 8 April 2021; Revised 13 July 2021; Accepted 27 July 2021; Published 14 August 2021

Academic Editor: Maria Lina Tornesello

Copyright ( 2021 Marco Delle Monache et al. This is an open access article distributed under the Creative Commons Attribution License, which permits unrestricted use, distribution, and reproduction in any medium, provided the original work is properly cited.

\begin{abstract}
Background. Noninvasive methods are useful for investigating patients with chronic HBV infection. The severity of liver disease in inactive HBsAg carriers can be noninvasively assessed by transient elastography (TE) alone or in association with biochemical markers of fibrosis. Objectives. The study evaluates the effectiveness of the TE compared to common fibrosis scores (FSs), APRI, Forns Index, and FIB4, for identifying significant fibrosis in Italian and foreigner HBsAg carriers. To investigate the risk of progression of the liver disease, liver stiffness (LS) and HBV-DNA were monitored over time. Methods. Viral load, biochemical parameters, and LS have been retrospectively evaluated in 125 putative inactive HBV carriers, who visited two outpatient departments (Colleferro Hospital and INMP) from 01/03/2014 to 31/12/2019. Differences in clinical, biochemical, and demographic variables between Italians and foreigners were analyzed. 66 of 125 patients were followed up for 24 months by monitoring liver stiffness and HBV-DNA. Results. Mean overall LS was $5.55 \pm 1.92 \mathrm{kPa} ; 18(14.4 \%)$ patients had a LS $\geq 7.5 \mathrm{kPa}$. Mean of APRI, Forns, and FIB4 was $0.29 \pm 0.11,4.15 \pm 1.63$, and $1.16 \pm 0.59$, respectively. FS did not differ between the patients with LS $<7.5 \mathrm{kPa}$ and those with LS $\geq 7.5 \mathrm{kPa}$. Italians displayed a significant lower ALT $(0.53 \pm 0.18$ vs. $0.67 \pm 0.33, p<0.05)$ and AST $(0.59 \pm 0.16$ vs. $0.70 \pm 0.21, p<0.01)$ value than foreigners. No differences in LS and HBV-DNA levels were observed. In 66 patients followed up for 24 months, HBV-DNA increased by $\geq 2000 \mathrm{UI} / \mathrm{ml}$ after 12 months in 15 individuals and remained $\geq 2000 \mathrm{UI} / \mathrm{ml}$ after 24 months in 10/15 individuals. 7/10 patients showed LS $\geq 7.5 \mathrm{kPa}$ after 24 months, and 4 of them underwent antiviral therapy for HBV. Patients with HBV-DNA $<2000 \mathrm{IU} / \mathrm{ml}$ had a significantly lower LS than those with HBV-DNA $\geq 2000 \mathrm{IU} / \mathrm{ml}(5.30 \pm 1.43 \mathrm{vs}$. $7.69 \pm 1.07, p<0.0001)$. Conclusions. Analysis shows lower effectiveness of FS vs. TE in the assessment of putative inactive HBV carriers. Furthermore, using FibroScan ${ }^{\circledR}$ and HBV-DNA can identify "false" inactive carriers.
\end{abstract}

\section{Background}

Hepatitis B virus (HBV) infection is a worldwide health problem. It is estimated, in fact, that HBV in the world has infected 2 billion people and that there are more than 350 million chronic carriers of the virus. This infection is widespread in some Eastern European countries with a prevalence of $4.4 \%$ of the population [1]. In Italy, the overall prevalence of $\mathrm{HBV}$ was equal to $0.6 \%$ in 2016. In comparison, immigrants from East-Europe living in Italy showed
HBsAg prevalence between $6.9 \%$ and $36.7 \%$ [2-5]. Infection by HBV can be responsible for liver diseases with different severities, from chronic hepatitis to cirrhosis and primary liver cancer. In asymptomatic patients, reactivation of the virus, i.e., a sudden increase in viral replication in previously inactive HBsAg carriers, is also possible and results in the development of chronic hepatitis.

In the past, liver biopsy (LB) was the gold standard for diagnosis and staging of chronic HBV liver disease. More recently, and according to the international guidelines $[6,7]$, 
inactive carriers of $\mathrm{HBsAg}$ are not subjected to invasive investigations, such as liver biopsy, but to noninvasive methods for the staging of liver disease, such as transient elastography (TE) alone or in association with fibrosis scores based on biochemical variables such as APRI, Forns Index, and FIB4 [6, 8-11]. These methods are easy, feasible, and well accepted by the patient and have sufficient accuracy [6]. Furthermore, according to some studies, they have similar results to $\mathrm{LB}$ and can be performed in patients of any age [6-10]. In the last two decades, noninvasive tests were used more frequently to evaluate patients with chronic $\mathrm{HCV}$ hepatitis [12] and nonalcoholic steatohepatitis (NASH) [13-18]. Furthermore, there is a good correlation between LS measured by FibroScan ${ }^{\circledR}$ and the stage of histological fibrosis in patients with HBV-positive cirrhosis [12, 13]. A meta-analysis [19] confirmed that TE has a good predictive value for advanced fibrosis (i.e., Metavir $\geq \mathrm{F} 2$ and Ishak $\geq$ S3). Finally, TE of the latest generation (with CAP) can investigate other causes of liver injury [12, 20, 21], such as NAFLD. However, TE has drawbacks, the most significant of which is that LS can be affected by certain clinical conditions such as liver inflammation [20] and fatty liver infiltration [12].

\section{Objectives}

The principal aim of this retrospective study was to evaluate the effectiveness of TE compared to common biochemical fibrosis tests such as APRI, Forns Index, and FIB4 to rule out the presence of advanced fibrosis in presumed inactive carriers of HBsAg. Furthermore, we compared in our study population some clinical characteristics (age, ALT, AST, liver stiffness, and HBV-DNA) of Italians versus foreigner patients. Finally, we followed up a subgroup of patients to monitor liver stiffness and HBV-DNA levels.

\section{Materials and Methods}

3.1. Cohort Recruitment and End Points. We retrospectively assessed the medical records of 125 presumed inactive HBsAg carriers admitted to 2 outpatient departments (Colleferro Hospital and INMP) from March 2014 to December 2019. Inclusion criteria were age 18-65 years, HBsAg positivity for at least 12 months associated with normal ALT levels, and HBV-DNA less than $2000 \mathrm{IU} / \mathrm{ml}$ for at least one year.

3.2. Transient Elastography. LS was measured in all subjects. All TEs were performed using Fibroscan (C) (Echosens, Paris) by experienced doctors following the manufacturer's instructions. Patients fasted for at least two hours were examined in the dorsal decubitus position with the right arm in maximum abduction. The tip of the transducer was placed on the skin in the right intercostal spaces above the liver. LS mean value $(\mathrm{kPa})$ was obtained from at least ten valid measurements excluding series with interquartile range $>30 \%$ and success $<60 \%$. LS was analyzed as a continuous and categorical variable $(<7.5 \mathrm{kPa}, \geq 7.5 \mathrm{kPa})$, through the value of $7.5 \mathrm{kPa}$ considered as the cutoff for significant fibrosis in the HBV setting [11].

3.3. Histological and Biochemical Data. Liver histology, when available, was evaluated for the degree of necroinflammation and stage of fibrosis according to Ishak score [22].

HBV-DNA levels were determined by real-time PCR (Cobas ${ }^{\circledR}$ Taqman $^{\circledR} 48$ Roche Molecular Diagnostics), and quantitative HBsAg assay (qHBsAg) was performed using the Elecsys Quant ${ }^{\circledR}$ HBsAg II Roche assay. HBV-DNA was analyzed as a continuous and categorical variable $(<2000 \mathrm{IU} / \mathrm{ml}$, $\geq 2000 \mathrm{IU} / \mathrm{ml}$ ), through the value of $2000 \mathrm{IU} / \mathrm{ml}$ considered as the cutoff.

Liver fibrosis scores were calculated by applying the corresponding formulas:

$$
\begin{aligned}
\mathrm{APRI} & =\frac{\mathrm{AST}(\mathrm{U} / \mathrm{L}) / \mathrm{AST}(\text { upper normal limit })}{\text { platelet count }\left(10^{9} / \mathrm{L}\right)} \times 100(7), \\
\mathrm{FIB}-4 & =\frac{\operatorname{age}(\text { years }) \times \operatorname{AST}(\mathrm{U} / \mathrm{L})}{\text { platelet } \operatorname{count}\left(10^{9} / \mathrm{L}\right) \times \sqrt{\mathrm{ALT}}(\mathrm{U} / \mathrm{L})}(9),
\end{aligned}
$$

Forns Index $=7.811-3.131 \ln \left(\operatorname{PLT}\left(\frac{109}{\mathrm{~L}}\right)\right)$

$$
\begin{aligned}
& +0.781 \ln (\gamma \mathrm{GT}(\mathrm{IU} / \mathrm{L})) \\
& +3.467 \ln (\operatorname{age}(y)) \\
& -0.014(\text { cholesterol }(\mathrm{mg} / \mathrm{dL}))(10) .
\end{aligned}
$$

The values of AST, ALT, and GGT are expressed as the ratio between the value and the upper limit of the laboratory range (AST and ALT: $40 \mathrm{IU}$; GGT $45 \mathrm{IU}$ ).

3.4. Clinical Management of Patients. According to the EASL guidelines on the management of HBV infection [7], we applied a locally modified clinical flow chart in order to initiate antiviral therapy in patients with active infection and signs of liver fibrosis (Figure 1).

Sixty six patients were followed up for 24 months, and liver stiffness was measured every 12 months. During the follow-up, patients were differentiated according to $\mathrm{HBV}$ DNA levels and LS: patients with DNA <2000 IU/ml and LS $<7.5 \mathrm{kPa}$ during the first year of follow-up were defined "true inactive" and monitored every 12 months for ALT, HBV-DNA, and LS every $2 / 3$ years, while patients with LS $\geq 7.5 \mathrm{kPa}$ were continued to be checked every 6 months for ALT, HBV-DNA, and LS every year. Patients who developed $\mathrm{HBV}$-DNA $\geq 2000$ and $\leq 20000 \mathrm{IU} / \mathrm{ml}$ during the follow-up, if LS was $<7.5$ and, when available, qHBsAg was $<1000 \mathrm{IU} / \mathrm{ml}$, were monitored with the same control intervals of the above. However, if $\mathrm{qHBsAg}$ was $\geq 1000 \mathrm{IU} / \mathrm{ml}$, they were checked every 3 months for ALT and HBV-DNA and LS every 6-12 months. Patients with HBV-DNA $\geq 2000$ and $\leq 20000 \mathrm{IU} / \mathrm{ml}, \mathrm{LS} \geq 7.5 \mathrm{kPa}$, and $\mathrm{qHBsAg}>1000 \mathrm{IU} / \mathrm{ml}$ underwent liver biopsy, if accepted, and began treatment if 


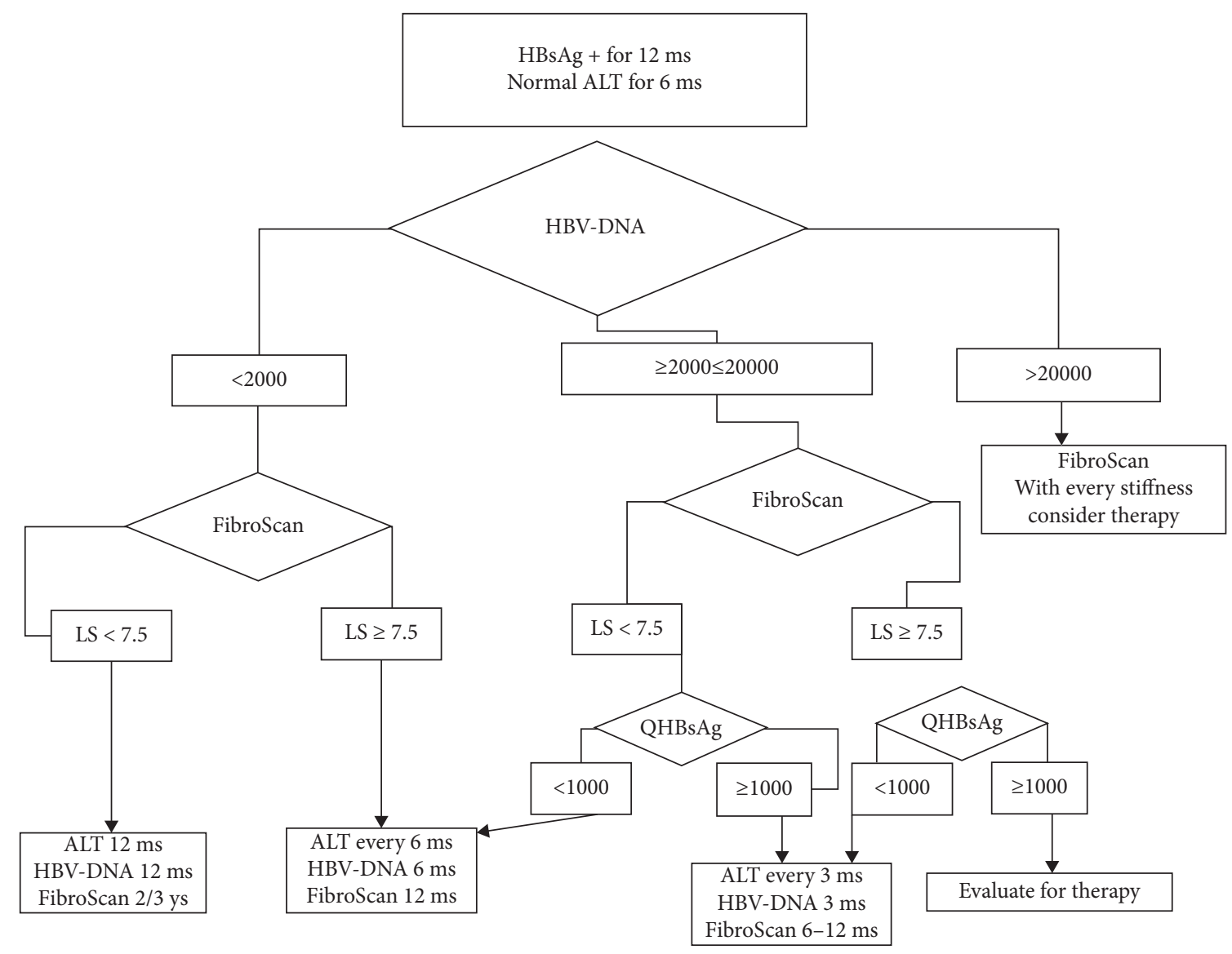

FIgURE 1: Clinical algorithm for the follow-up and management of putative inactive HBsAg carriers.

significant fibrosis was confirmed. Patients who developed during follow-up a HBV-DNA >20000 had a liver fibrosis evaluation and received antiviral treatment, regardless of liver stiffness.

3.5. Statistical Analysis. Baseline characteristics including demographical, biochemical, and liver elastographic variables of study population of 125 patients were presented as frequencies and mean \pm standard deviation (SD). To analyze the existence of statistically significant differences in fibrosis scores according to liver stiffness $(<7.5 \mathrm{kPa}, \geq 7.5 \mathrm{kPa})$, we performed the Wilcoxon test. We also tested the differences in clinical variables between Italians and foreigners through the Chi-square test and Wilcoxon test. Finally, in a subgroup of 66 patients followed up for 24 months, we analyzed the changes in HBV-DNA and liver stiffness during the follow-up through the Wilcoxon paired test and $\mathrm{McNemar}$ test and we tested the relation between HBV-DNA and liver stiffness through the Wilcoxon test and Fisher's test. We considered test results with $p<0.05$ as statistically significant. All analyses were performed using statistical analysis software (SAS).

\section{Results}

Of the 125 patients enrolled, number of males was 77 (66\%) and Italians was $75(60 \%)$; the mean age was 46.5 years. Among foreigners, 27 (54\%) were from countries of the
Eastern Europe, mainly from Romania ( $n=15,30 \%), 18$ (36\%) from Africa, 4 (8\%) from Asia, and 1 (2\%) from South America.

In the study population of 125 patients, mean LS was $5.55 \mathrm{kPa}( \pm 1.92 \mathrm{SD}) ; 18(14.4 \%)$ patients had a LS $\geq 7.5 \mathrm{kPa}$. The mean value of APRI was $0.29( \pm 0.11 \mathrm{SD})$; the mean values of Forns Index and FIB4 score were 4.15 ( \pm 1.63 SD) and $1.16( \pm 0.59 \mathrm{SD})$, respectively (Table 1$)$.

As shown in Table 2, Italians were significantly older than foreigners (mean \pm SD: $53.1 \pm 11.9$ vs. $36.5 \pm 10.2$, $p<0.0001)$. Moreover, Italians, compared to foreigner patients, presented statistically significant lower values of ALT (mean \pm SD: $0.53 \pm 0.18$ vs. $0.67 \pm 0.33, p<0.05$ ) and AST (mean \pm SD: $0.59 \pm 0.16$ vs. $0.70 \pm 0.21, p<0.01$ ). Nevertheless, in both groups, the values of ALT and AST were in the normal range. No statistically significant differences were observed in LS and HBV-DNA distributions between Italians and foreigners.

Fibrosis score (APRI, Forns Index, and FIB4) distributions did not differ between patients with $\mathrm{LS}<7.5 \mathrm{kPa}$ and those with LS $\geq 7.5 \mathrm{kPa}$ (Table 3 ).

In the subgroup of 66 patients, we analyzed HBV-DNA and LS values at basal time, after 12 months and after 24 months. HBV-DNA increased to $\geq 2000 \mathrm{UI} / \mathrm{ml}$ after 12 months in 15 individuals and remained $\geq 2000 \mathrm{UI} / \mathrm{ml}$ after 24 months in 10 of 15 individuals. Seven of these 10 patients showed LS $\geq 7.5 \mathrm{kPa}$ still after 24 months, and 4 of them, 
TABLE 1: Baseline characteristics of the included 125 patients.

\begin{tabular}{lc}
\hline Characteristics & Results \\
\hline Patients, $n$ & 125 \\
Age (years) & $46.5 \pm 13.8$ \\
Gender & $77(61.6 \%)$ \\
Male, $n(\%)$ & $48(38.4 \%)$ \\
Female, $n(\%)$ & $75(60.0 \%)$ \\
Citizenship & $50(40.0 \%)$ \\
Italians, $n(\%)$ & $0.59 \pm 0.26$ \\
Foreigners, $n(\%)$ & $0.64 \pm 0.19$ \\
ALT & $3747.46 \pm 13883.25$ \\
AST & $91(72.8 \%)$ \\
HBV-DNA & $34(27.2 \%)$ \\
HBV-DNA $<2000 \mathrm{IU} / \mathrm{ml}, n(\%)$ & $4(3.2 \%)$ \\
HBV-DNA $\geq 2000 \mathrm{IU} / \mathrm{ml}, n(\%)$ & $5.55 \pm 1.92$ \\
HBV-DNA $>20000 \mathrm{IU} / \mathrm{ml}, n(\%)$ & $107(85.6 \%)$ \\
Liver stiffness $(\mathrm{kPa})$ & $18(14.4 \%)$ \\
LS $<7.5 \mathrm{kPa}, n(\%)$ & $0.29 \pm 0.11$ \\
LS $\geq 7.5 \mathrm{kPa}, n(\%)$ & $4.15 \pm 1.63$ \\
APRI & $1.16 \pm 059$ \\
Forns Index & \\
FIB4 &
\end{tabular}

Continuous values are expressed as mean \pm standard deviation (SD). ALT and AST are expressed as multiples of upper limit of normal.

TABLE 2: Characteristics of Italians versus foreigners among 125 patients.

\begin{tabular}{|c|c|c|c|}
\hline Characteristics & Italians $(n=75)$ & Foreigners $(n=50)$ & $p$ \\
\hline Age (years) & $53.1 \pm 11.9$ & $36.5 \pm 10.2$ & $<0.0001$ \\
\hline ALT & $0.53 \pm 0.18$ & $0.67 \pm 0.33$ & $<0.05$ \\
\hline AST & $0.59 \pm 0.16$ & $0.70 \pm 0.21$ & $<0.01$ \\
\hline Liver stiffness $(\mathrm{kPa})$ & $5.59 \pm 1.92$ & $5.50 \pm 1.94$ & Ns \\
\hline $\mathrm{LS}<7.5 \mathrm{kPa}, n(\%)$ & $64(85.3 \%)$ & $43(86.0 \%)$ & \multirow{2}{*}{ Ns } \\
\hline $\mathrm{LS} \geq 7.5 \mathrm{kPa}, n(\%)$ & $11(14.7 \%)$ & $7(14.0 \%)$ & \\
\hline HBV-DNA & $3107.29 \pm 8975.52$ & $4707.72 \pm 19092.72$ & Ns \\
\hline HBV-DNA <2000 IU/ml, $n(\%)$ & $58(77.3 \%)$ & $33(66.0 \%)$ & \multirow{2}{*}{ Ns } \\
\hline HBV-DNA $\geq 2000 \mathrm{IU} / \mathrm{ml}, n(\%)$ & $17(22.7 \%)$ & $17(34.0 \%)$ & \\
\hline
\end{tabular}

Continuous variables are expressed as mean \pm standard deviation (SD). A $p$ value $<0.05$ is considered significant (Wilcoxon test). ALT and AST are expressed as multiples of upper limit of normal. For categorical variables, a $p$ value $<0.05$ is considered significant (Chi-squared test).

TABLE 3: Fibrosis score results according to LS among 125 patients.

\begin{tabular}{lccc}
\hline Characteristics & $\begin{array}{c}\mathrm{LS}<7.5 \mathrm{kPa} \\
(n=107)\end{array}$ & $\begin{array}{c}\mathrm{LS} \geq 7.5 \mathrm{kPa} \\
(n=18)\end{array}$ & $p$ \\
\hline APRI & $0.28 \pm 0.09$ & $0.35 \pm 0.18$ & $\mathrm{Ns}$ \\
Forns Index & $4.14 \pm 1.55$ & $4.17 \pm 2.06$ & $\mathrm{Ns}$ \\
FIB4 & $1.15 \pm 0.60$ & $1.21 \pm 0.59$ & $\mathrm{Ns}$ \\
\hline
\end{tabular}

All values are expressed as mean \pm standard deviation $(\mathrm{SD})$. A $p$ value $<0.05$ is considered significant (Wilcoxon test).

showing a moderate fibrosis (Ishak $S \geq 3$ ) at liver biopsy, underwent antiviral therapy for HBV, and the other 3 patients refused liver biopsy and dropped out from the study.

Patients remaining with HBV-DNA $<2000 \mathrm{IU} / \mathrm{ml}$ during the follow-up had a significantly lower LS distribution at 24 months than those with which HBV-DNA increased to $\geq 2000 \mathrm{IU} / \mathrm{ml}$ during the follow-up (mean \pm SD: $5.30 \pm 1.43$ vs. $7.69 \pm 1.07, p<0.0001)$.

During the follow-up mean, HBV-DNA value increased significantly (mean \pm SD: $561.80 \pm 620.01$ at basal time vs. $5202.76 \pm 19597.25$ at 24 months, $p<0.001$ ), while mean LS value did not present significant change over time (mean \pm SD: $5.80 \pm 2.29$ at basal time vs. $5.67 \pm 1.62$ at 24 months); patients with $\mathrm{LS} \geq 7.5 \mathrm{kPa}$ had a slight decrease from 16 at basal time to 12 after 2 years (Table 4 ).

Finally, in the subgroup of 66 patients followed for 24 months, we analyzed the relation between LS and HBVDNA values: at basal time, all the patients presented HBVDNA $<2000 \mathrm{UI} / \mathrm{ml}$ and they had a LS mean distribution equal to $5.80( \pm 2.29 \mathrm{SD})$; at 12 months, LS values differed significantly between patients with HBV-DNA $<2000 \mathrm{UI} / \mathrm{ml}$ $(n=51)$ and HBV-DNA $\geq 2000 \mathrm{UI} / \mathrm{ml}(n=15)(5.33 \pm 1.22$ vs. $6.79 \pm 1.55, p<0.001$ ); at 24 months, LS values differed significantly between patients with HBV-DNA $<2000 \mathrm{UI} / \mathrm{ml}$ $(n=56)$ and HBV-DNA $\geq 2000 \mathrm{UI} / \mathrm{ml}(n=10)(5.30 \pm 1.43$ vs. $6.79 \pm 1.55, p<0.0001)$ (Table 5).

\section{Discussion}

In our setting of putative inactive HBV carriers, the application of an easy and feasible algorithm coupling HBVDNA and LS measurement allowed us to identify patients 
TABLE 4: HBV-DNA and liver stiffness in the subgroup of 66 patients during the follow-up.

\begin{tabular}{|c|c|c|c|c|c|}
\hline \multirow[t]{2}{*}{ Characteristics } & \multirow[t]{2}{*}{ Basal time } & \multirow[t]{2}{*}{12 months } & \multirow[t]{2}{*}{24 months } & \multicolumn{2}{|c|}{$\begin{array}{c}\text { Change ( } 24 \text { months, } \\
\text { basal time) }\end{array}$} \\
\hline & & & & $\%$ change & $p$ value \\
\hline HBV-DNA & $561.80 \pm 620.01$ & $5200.27 \pm 18666.56$ & $5202.76 \pm 19597.25$ & 826.1 & $<0.001$ \\
\hline HBV-DNA <2000 UI/ml, $n(\%)$ & $66(100 \%)$ & $51(77.3 \%)$ & $56(84.8 \%)$ & -15.2 & \\
\hline HBV-DNA $\geq 2000 \mathrm{UI} / \mathrm{ml}, n(\%)$ & $0(0 \%)$ & $15(22.7 \%)$ & $10(15.2 \%)$ & 100.0 & \\
\hline Liver stiffness $(\mathrm{kPa})$ & $5.80 \pm 2.29$ & $5.66 \pm 1.43$ & $5.67 \pm 1.62$ & -2.2 & Ns \\
\hline $\mathrm{LS}<7.5 \mathrm{kPa}, n(\%)$ & $50(75.8 \%)$ & $54(81.8 \%)$ & $54(81.8 \%)$ & 8.0 & \\
\hline $\mathrm{LS} \geq 7.5 \mathrm{kPa}, n(\%)$ & $16(24.2 \%)$ & $12(18.2 \%)$ & $12(18.2 \%)$ & -25.0 & Ns \\
\hline
\end{tabular}

Continuous variables are expressed as mean \pm standard deviation (SD). A $p$ value $<0.05$ is considered significant (Wilcoxon paired test). For categorical variables, a $p$ value $<0.05$ is considered significant (McNemer's test).

TABle 5: Relation between HBV-DNA and liver stiffness in the subgroup of 66 patients during the follow-up.

\begin{tabular}{|c|c|c|c|}
\hline Characteristics & HBV-DNA <2000 UI/ml & HBV-DNA $\geq 2000 \mathrm{UI} / \mathrm{ml}$ & $p$ value \\
\hline \multicolumn{4}{|c|}{ Basal time } \\
\hline Liver stiffness $(\mathrm{kPa})$ & $5.80 \pm 2.29$ & - & - \\
\hline $\mathrm{LS}<7.5 \mathrm{kPa}, n(\%)$ & $50(100 \%)$ & $0(0 \%)$ & \\
\hline $\mathrm{LS} \geq 7.5 \mathrm{kPa}, n(\%)$ & $16(100 \%)$ & $0(0 \%)$ & - \\
\hline \multicolumn{4}{|c|}{12 months } \\
\hline Liver stiffness $(\mathrm{kPa})$ & $5.33 \pm 1.22$ & $6.79 \pm 1.55$ & $<0.001$ \\
\hline $\mathrm{LS}<7.5 \mathrm{kPa} n(\%)$ & $47(87.0 \%)$ & $7(13.0 \%)$ & \\
\hline $\mathrm{LS} \geq 7.5 \mathrm{kPa} n(\%)$ & $4(33.3 \%)$ & $8(66.7 \%)$ & $<0.001$ \\
\hline \multicolumn{4}{|c|}{24 months } \\
\hline Liver stiffness $(\mathrm{kPa})$ & $5.30 \pm 1.43$ & $7.69 \pm 1.07$ & $<0.0001$ \\
\hline $\mathrm{LS}<7.5 \mathrm{kPa}, n(\%)$ & $51(94.4 \%)$ & $3(5.6 \%)$ & \\
\hline $\mathrm{LS} \geq 7.5 \mathrm{kPa}, n(\%)$ & $5(41.7 \%)$ & $7(58.3 \%)$ & $<0.0001$ \\
\hline
\end{tabular}

Continuous variable are expressed as mean \pm standard deviation (SD). A $p$ value $<0.05$ is considered significant (Wilcoxon test). For categorical variables, a $p$ value $<0.05$ is considered significant (Fisher's test).

with a progressive liver disease requiring antiviral therapy in 4 of 66 cases $(6 \%)$ during a follow-up of 24 months.

The definition of a so-called "HBV-inactive carrier" is based on repeated and stable ALT normality and HBV-DNA $<2000 \mathrm{IU} / \mathrm{ml}$ associated with normal findings at liver ultrasound (US). LB is an invasive test not recommended in these patients. TE is a noninvasive tool, easy, feasible, and reproducible, to investigate and follow up these patients $[6,7]$.

The use of combined scores of fibrosis in patients with $\mathrm{HBV}$ infection is controversial: for some authors, these tests could be helpful in the screening of patients with HBV infection $[23,24]$, but no studies have investigated their effectiveness in a cohort of putative inactive HBV carriers. Instead, our data suggested that noninvasive scores of fibrosis used (APRI test, Forns Index, and FIB4) do not allow to identify subjects with significant fibrosis ( $\mathrm{LS} \geq 7.5 \mathrm{kPa})$ nor individuals with high viral load (HBV-DNA $\geq 2000 \mathrm{IU} / \mathrm{ml}$ ) in this setting. Therefore, these tests are not useful in the initial assessment of the putative inactive $\mathrm{HBV}$ carrier and in the following controls.

In the initial evaluation of the inactive $\mathrm{HBV}$ carrier, FibroScan ${ }^{\circledR}$ is mandatory, coupled with quantitative HBsAg determination, when available. Patients with HBV-DNA levels between 2000 and $20000 \mathrm{IU} / \mathrm{ml}$, previously called "grey zone," cannot be considered "tout court" inactive carriers, but for patients with active viral replication and thus with potentially progressive liver disease $[7,25]$, a more strict biochemical follow-up (every 3-6 months) and a TE every 12 months is recommended [7]. In fact, it could allow us to identify a "HBV false inactive carrier," with an active liver disease as confirmed by a subsequent liver biopsy (Figure 1).

Another critical point of this study is the identification of other concomitant causes of liver disease in so-called inactive carriers. Already, Oliveri et al. in their study [20] identified among 188 patients a group of 17 (9\%) as "inactive carriers with liver disease" having a significant liver stiffness. In these patients, causes other than viruses (metabolic, toxic, or unidentified) may produce liver disease or potentially contribute to its progression. In our follow-up group, these patients were about 5/51 (9.8\%) (Table 5), in accordance with the data of the other authors. Therefore, false inactive carriers of the virus with cofactors of the disease should undergo, in addition to the initial screening for other causes of chronic liver disease (i.e., autoimmune, genetic, and toxic), a quantitative evaluation of steatosis either by ultrasound score of Hamaguchi [16] or controlled attenuation parameter (CAP) measurement if available [15], and the calculation of Fatty Liver Index [14] and the most used score of fibrosis (NAFLD Fibrosis Score, BARD) [17, 18]. It is in fact known that the cutoffs of FibroScan ${ }^{\circledR}$ vary according to the etiology of liver disease $[11,12]$, and therefore, it would be useful to propose studies evaluating patients with double etiology (viral and NAFLD) in order to find an algorithm applicable to FibroScan ${ }^{\circledR}$ for correction of the final result in 
such patients. The finding in our study population of some individuals with $\mathrm{LS} \geq 7.5$ could be due to fibrosis caused by previous hepatitis flares and to the presence of multifactorial liver disease. The availability of quantitative determination of $\mathrm{HBsAg}$ test as applicable to all HBsAg positive cases allows, hypothetically, to identify more accurately the patients with transcriptionally active cccDNA and thus able to develop progressive disease [25]. Although this information cannot be deduced from our observational study, the test was applied only in a subgroup of patients with higher probability of falsely inactive infection (HBV-DNA $\geq 2000$ and $\leq 20000 \mathrm{IU} / \mathrm{ml})$.

\section{Conclusions}

In conclusion, in our study, we confirmed that FibroScan ${ }^{\circledR}$ is a simple and reproducible method for noninvasive assessment of liver fibrosis in the so-called inactive carrier of HBV and is potentially very useful in clinical practice for the staging of these patients [7]. An optimal timing for the execution of FibroScan ${ }^{\circledR}$ in putative inactive HBsAg carriers is not yet determined, but probably on the basis of our data, testing repetition every 6-36 months (according to our flow chart) should rule out false inactive carriers with a potentially progressive liver disease.

\section{Data Availability}

All data generated or analyzed during this study are included within this article.

\section{Conflicts of Interest}

The authors declare that there are no conflicts of interest.

\section{References}

[1] European Centre for Disease Prevention and Control, Systematic Review on Hepatitis $B$ and C Prevalence in the EU/ EEA, ECDC, Stockholm, Sweden, 2016.

[2] G. Scotto, D. Martinelli, R. Di Tullio, and V. Fazio, "Epidemiological and clinical features of Hepatitis B virus genotypes among immigrants in southern Italy," Hepatitis Research and Treatment, vol. 2010, Article ID 878356, 6 pages, 2010.

[3] S. Majori, V. Baldo, I. Tommasi et al., "Hepatitis A, B, and C infection in a community of sub-saharan immigrants living in verona (Italy)," Journal of Travel Medicine, vol. 15, no. 5, pp. 323-327, 2008.

[4] N. Coppola, L. Alessio, L. Gualdieri et al., "Hepatitis B virus, hepatitis $\mathrm{C}$ virus and human immunodeficiency virus infection in undocumented migrants and refugees in southern Italy, January 2012 to June 2013," Eurosurveillance, vol. 20, no. 35, Article ID 30009, 2015.

[5] I. El-Hamad, M. C. Pezzoli, E. Chiari et al., "Point-of-care screening, prevalence, and risk factors for hepatitis B infection among 3,728 mainly undocumented migrants from non-EU countries in northern Italy," Journal of Travel Medicine, vol. 22, no. 2, pp. 78-86, 2015.

[6] M. Fraquelli and F. Branchi, "The role of transient elastography in patients with hepatitis B viral disease," Digestive and Liver Disease, vol. 43, pp. S25-S31, 2011.
[7] European Association for the Study of the Liver, "EASL 2017 clinical practice guidelines on the management of hepatitis B virus infection," Journal of Hepatology, vol. 67, no. 2, pp. 370-398, 2017.

[8] C. Wai, J. K. Greenson, R. J. Fontana et al., "A simple noninvasive index can predict both significant fibrosis and cirrhosis in patients with chronic hepatitis C," Hepatology, vol. 38, no. 2, pp. 518-526, 2003.

[9] R. K. Sterling, E. Lissen, N. Clumeck et al., "Development of a simple noninvasive index to predict significant fibrosis in patients with HIV/HCV coinfection," Hepatology, vol. 43, no. 6, pp. 1317-1325, 2006.

[10] X. Forns, S. Ampurdanès, J. M. Llovet et al., "Identification of chronic hepatitis C patients without hepatic fibrosis by a simple predictive model," Hepatology (Baltimore, Md.), vol. 36, no. 4 Pt 1, pp. 986-992, 2002.

[11] M. Fraquelli, C. Rigamonti, G. Casazza et al., "Etiology-related determinants of liver stiffness values in chronic viral hepatitis B or C," Journal of Hepatology, vol. 54, no. 4, pp. 621-628, 2011.

[12] L. Castera, X. Forns, and A. Alberti, "Non-invasive evaluation of liver fibrosis using transient elastography," Journal of Hepatology, vol. 48, no. 5, pp. 835-847, 2008.

[13] F. Branchi, C. B. Conti, A. Baccarin, P. Lampertico, D. Conte, and M. Fraquelli, "Non-invasive assessment of liver fibrosis in chronic hepatitis B," World Journal of Gastroenterology, vol. 20, no. 40, pp. 14568-14580, 2014.

[14] G. Bedogni, S. Bellentani, L. Miglioli et al., "The fatty liver index: a simple and accurate predictor of hepatic steatosis in the general population," BMC Gastroenterology, vol. 6, no. 1, p. 33, 20062.

[15] M. Sasso, V. Miette, L. Sandrin, and M. Beaugrand, "The controlled attenuation parameter (CAP): a novel tool for the non-invasive evaluation of steatosis using Fibroscan," Clinics and Research in Hepatology and Gastroenterology, vol. 36, no. 1, pp. 13-20, 2012.

[16] M. Hamaguchi, T. Kojima, Y. Itoh et al., "The severity of ultrasonographic findings in nonalcoholic fatty liver disease reflects the metabolic syndrome and visceral fat accumulation," The American Journal of Gastroenterology, vol. 102, no. 12, pp. 2708-2715, 2007.

[17] P. Angulo, J. M. Hui, G. Marchesini et al., "The NAFLD fibrosis score: a noninvasive system that identifies liver fibrosis in patients with NAFLD," Hepatology, vol. 45, no. 4, pp. 846-854, 2007.

[18] S. A. Harrison, D. Oliver, H. L. Arnold, S. Gogia, and B. A. Neuschwander-Tetri, "Development and validation of a simple NAFLD clinical scoring system for identifying patients without advanced disease," Gut, vol. 57, no. 10, pp. 1441-1447, 2008.

[19] Y. E. Chon, E. H. Choi, K. J. Song et al., "Performance of transient elastography for the staging of liver fibrosis in patients with chronic hepatitis B: a meta-analysis," PLoS One, vol. 7, no. 9, Article ID e44930, 2012.

[20] F. Oliveri, B. Coco, P. Ciccorossi et al., "Liver stiffness in the hepatitis B virus carrier: a non-invasive marker of liver disease influenced by the pattern of transaminases," World Journal of Gastroenterology, vol. 14, no. 40, pp. 6154-6162, 2008.

[21] G. V. Papatheodoridis, S. Manolakopoulos, Y.-F. Liaw, and A. Lok, "Follow-up and indications for liver biopsy in HBeAgnegative chronic hepatitis B virus infection with persistently normal ALT: a systematic review," Journal of Hepatology, vol. 57, no. 1, pp. 196-202, 2012. 
[22] R. G. Knodell, K. G. Ishak, W. C. Black et al., "Formulation and application of a numerical scoring system for assessing histological activity in asymptomatic chronic active hepatitis," Hepatology, vol. 1, no. 5, pp. 431-435, 1981.

[23] L. Castéra, P.-H. Bernard, B. Le Bail et al., "Transient elastography and biomarkers for liver fibrosis assessment and follow-up of inactive hepatitis B carriers," Alimentary Pharmacology \& Therapeutics, vol. 33, no. 4, pp. 455-465, 2011.

[24] World Health Organization, Guidelines for the prevention care and treatment of persons with chronic hepatitis B infection, World Health Organization, Geneva, Switzerland, 2015, https://apps.who.int/iris/bitstream/10665/154590/1/978924154 9059_eng.pdf.

[25] M. R. Brunetto, F. Oliveri, P. Colombatto et al., "Hepatitis B surface antigen serum levels help to distinguish active from inactive Hepatitis B virus genotype D carriers," Gastroenterology, vol. 139, no. 2, pp. 483-490, 2010. 